\title{
A STUDY THE PROBLEMS OF AUTO RICKSHAW DRIVERS IN KOLHAPUR CITY USING STATISTICAL TOOLS AND TECHNIQUES
}

\author{
Prakash S. Chougule ${ }^{1}$ \\ ${ }^{1}$ Associate Professor, \\ Rajarshi Chhatrapati Shahu College, \\ Kolhapur(MS), \\ India
S. V.Patil ${ }^{3}$
${ }^{3}$ Associate Professor,
Rajarshi Chhatrapati Shahu College,
Kolhapur(MS),
India
Bhavana A.Kumbhare 5
${ }^{5}$ Research Student,
Kolhapur(MS),
India \\ Rajarshi Chhatrapati Shahu College,
}

\author{
Tejaswi S.Kurane ${ }^{2}$ \\ ${ }^{2}$ Assistant Professor, \\ Rajarshi Chhatrapati Shahu College, \\ Kolhapur(MS), \\ India
}

\author{
Dhanaji M.Kamble ${ }^{4}$ \\ ${ }^{4}$ Research Student, \\ Rajarshi Chhatrapati Shahu College, \\ Kolhapur(MS), \\ India
}

\author{
Sumit K. Waghamare ${ }^{6}$ \\ ${ }^{6}$ Research Student, \\ Rajarshi Chhatrapati Shahu College, \\ Kolhapur(MS), \\ India
}

Article DOI: https://doi.org/10.36713/epra5607

\begin{abstract}
Health is a very significant matter in the daily life of a vehicle driver. The aim of this study is to identify the problems among the auto rickshaw service providers in relation to their standard of living and the number of hours put in driving the auto rickshaws, their life style, economic status, technology awareness, educational status, awareness about insurance. For this purpose, a well designed questionnaire prepared for collection of primary data containing various attributes and was circulated to 125 auto rickshaw drivers through convenient sampling technique and The data had been collected from different location in Kolhapur city. The collected data were then analysed with the help of various statistical tools and techniques to know the socio economic lifestyle of the autorickshaw drivers in kolhapur city. In our study the obtained results shows revealed major issues and backlogs in their socio economic lifestyle.
\end{abstract}

KEYWORDS: Graphical Representation, Large Test, Small Test, Level of significance.

\section{INTRODUCTION}

Auto rickshaw drivers in India have different life style. They work on daily basis and earn enough money to spend with their family. Rickshaw drivers with their humble behavior and hard work, earn money by taking the passengers to their destination. He is unable to buy his own rickshaw on his bases that's why, he takes loan from bank to buying rickshaw or he rent it for a rickshaw's owner. He works day in, day out. The hard work by rickshaw driver does not match the money for their fulfillment. Most of the times people try to pay him less. Rickshaw drivers want easy cash so he takes more passengers in a day and hard work. His life is simple life as he as to stand near road intersection and wait for passengers. He is one of the reasons for traffic. 
An auto rickshaw provides door to door service and acts as a feeder mode to public trans, generally of train commuters using rickshaw to access the station. While auto rickshaw serves an integral transport role to resident of Kolhapur. We aim to answer some of the following questions; How many hours they drive? How much time to waiting for passengers? What is there education qualification?

They face many problems and had to go through several messy situations, but still people try to pay them less. A rickshaw driver have not sufficient income to there expenditure.

So in this study we try to analyze the lifestyle of auto rickshaw drivers in Kolhapur city.

\section{OBJECTIVES}

$>$ To study the lifestyle of auto drivers in Kolhapur city

$>$ To study economic status of auto drivers

$>$ To study the technology awareness in auto drivers

$>$ To study the educational status of auto drivers

$>$ To study of family status of auto drivers

$>$ To study of insurance of auto and his family

$>$ To study the health problems of auto drivers

$>$ To study of no. of E-meter's in Kolhapur city

$>$ To study the company of auto rickshaws

\section{METHODOLOGY}

To study we have selected auto rickshaw driver we have C.B.S, Kadamwadi, shivajiputala, Sadarbajar, Nagala Park and Tarabai Park from this study.

There are total 100 Drivers in C.B.S. Stand, 30 Drivers in Kadamwadi, 50 Drivers in Shivajiputala, 40 Drivers in Sadarbajar, 30 Drivers in Nagala Park, and 25 Drivers in Tarabai Park. We have selected 32 Drivers from C.B.S. Stand, 10 Drivers from Kadamwadi, 31 Drivers from Shivajiputala, 29 Drivers from Sadarbajar, 13 Drivers from Nagala Park, 10 Drivers from Tarabai park Therefore the total sample size of 125 Drivers considered.

In this study, we have observed they face many problems and had to go through several messy situations, but still people try to pay them less, High traffic, Bad condition of road, competition of government vehicles.

\section{Method of data collection}

We have collected data from C.B.S. Stand, Kadamwadi , Shivajiputala, Sadarbajar, Nagala park, Tarabai park of size $32,10,31,29,13$ and 10 respctively.This study was conducted with a "interview" method. While information collecting from the auto stop is useful for making correct decision about the problem of auto drivers.following are some photographs of data collection

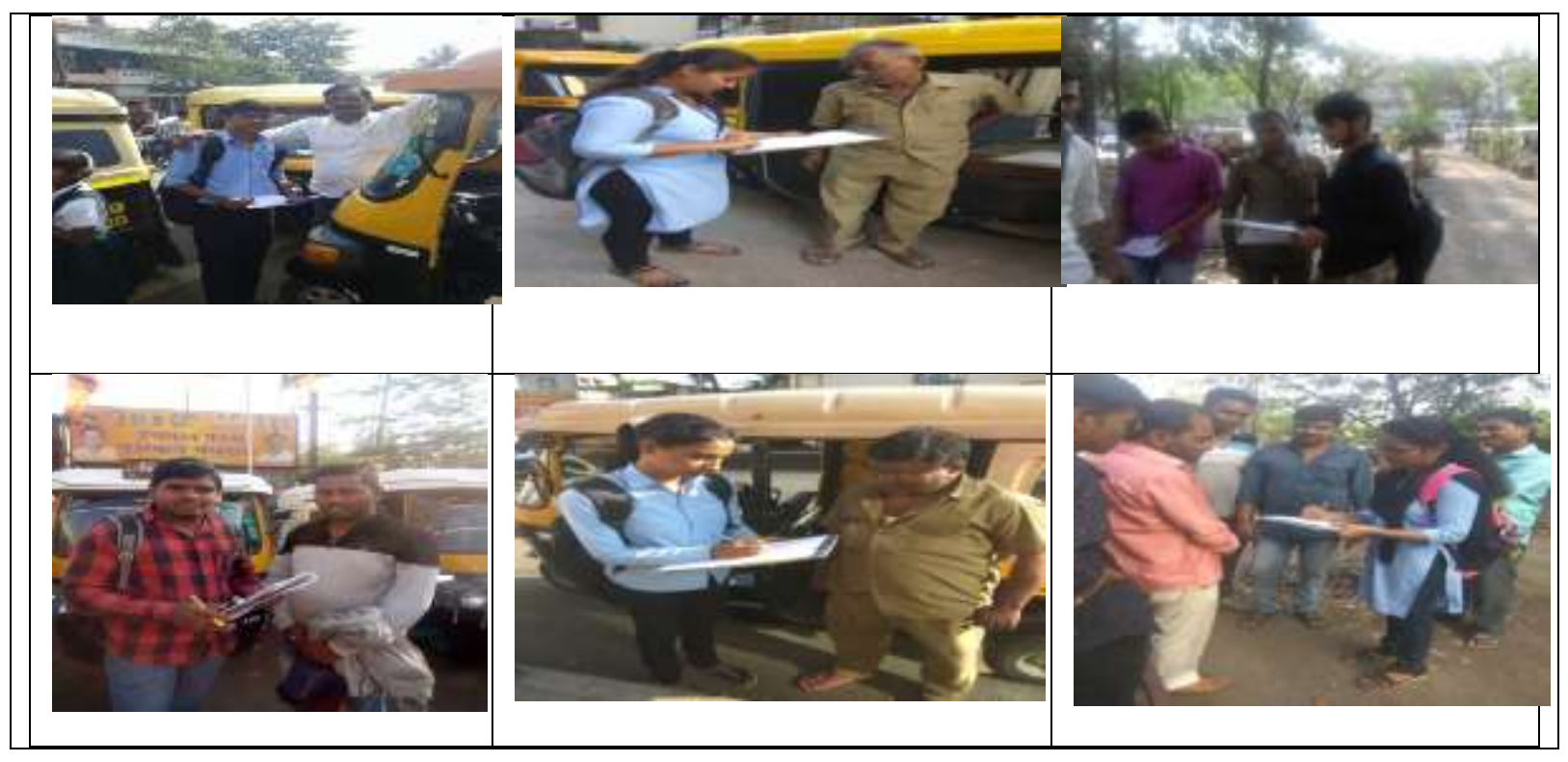

Statistical tools used:

- Graphical representation

- Testing of hypothesis
Software used:

$>$ MS-Excel

$>$ Microsoft Word

$>$ R-software 
EPRA International Journal of Multidisciplinary Research (IJMR) - Peer Reviewed Journal

Volume: 6 | Issue: 11 |November 2020 || Journal DOI: 10.36713/epra2013 || SJIF Impact Factor: 7.032 ||ISI Value: 1.188

GRAPHICAL REPRESENTATION

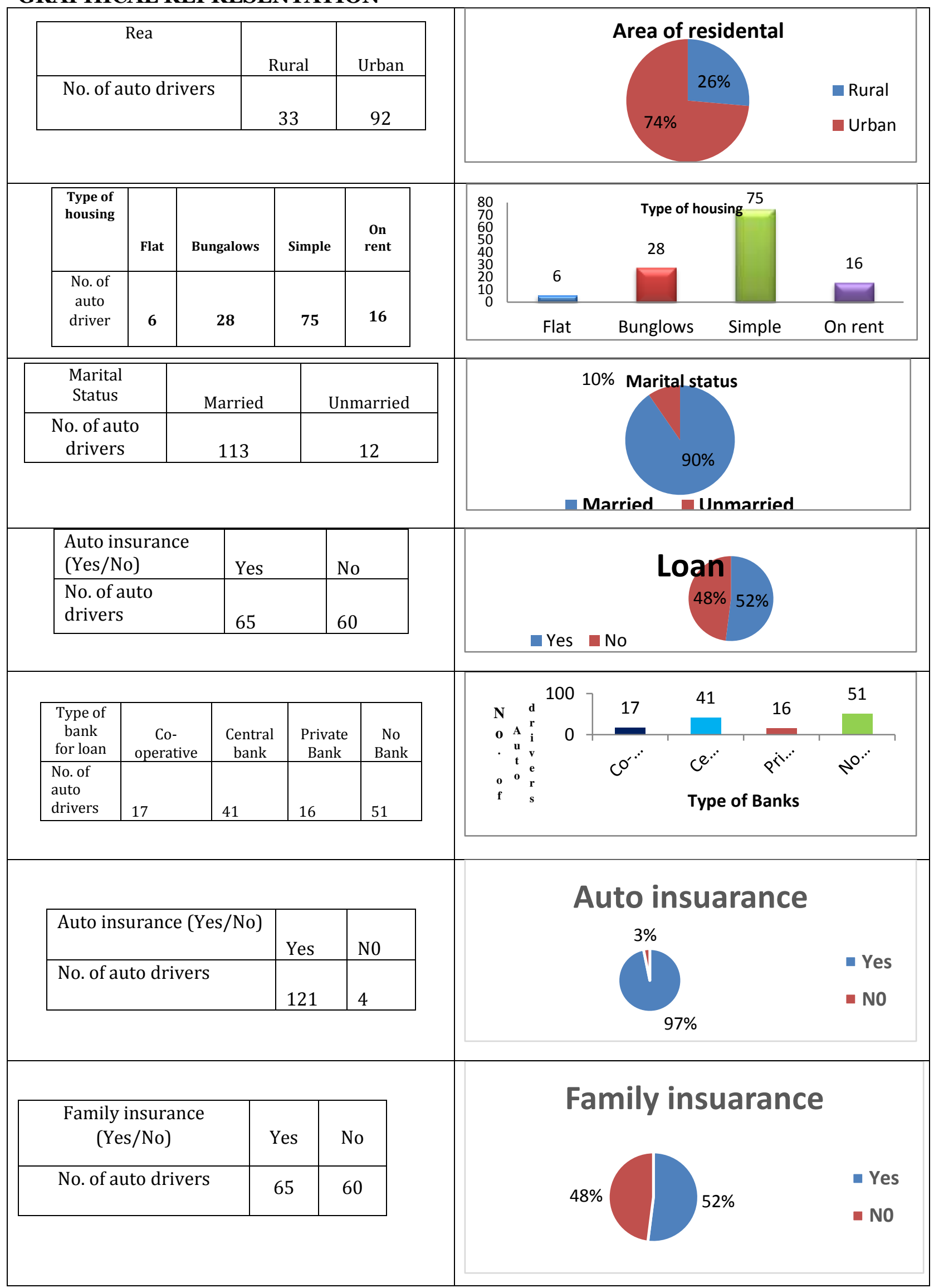


EPRA International Journal of Multidisciplinary Research (IJMR) - Peer Reviewed Journal

Volume: 6 | Issue: 11 |November 2020 || Journal DOI: 10.36713/epra2013 || SJIF Impact Factor: 7.032 ||ISI Value: 1.188

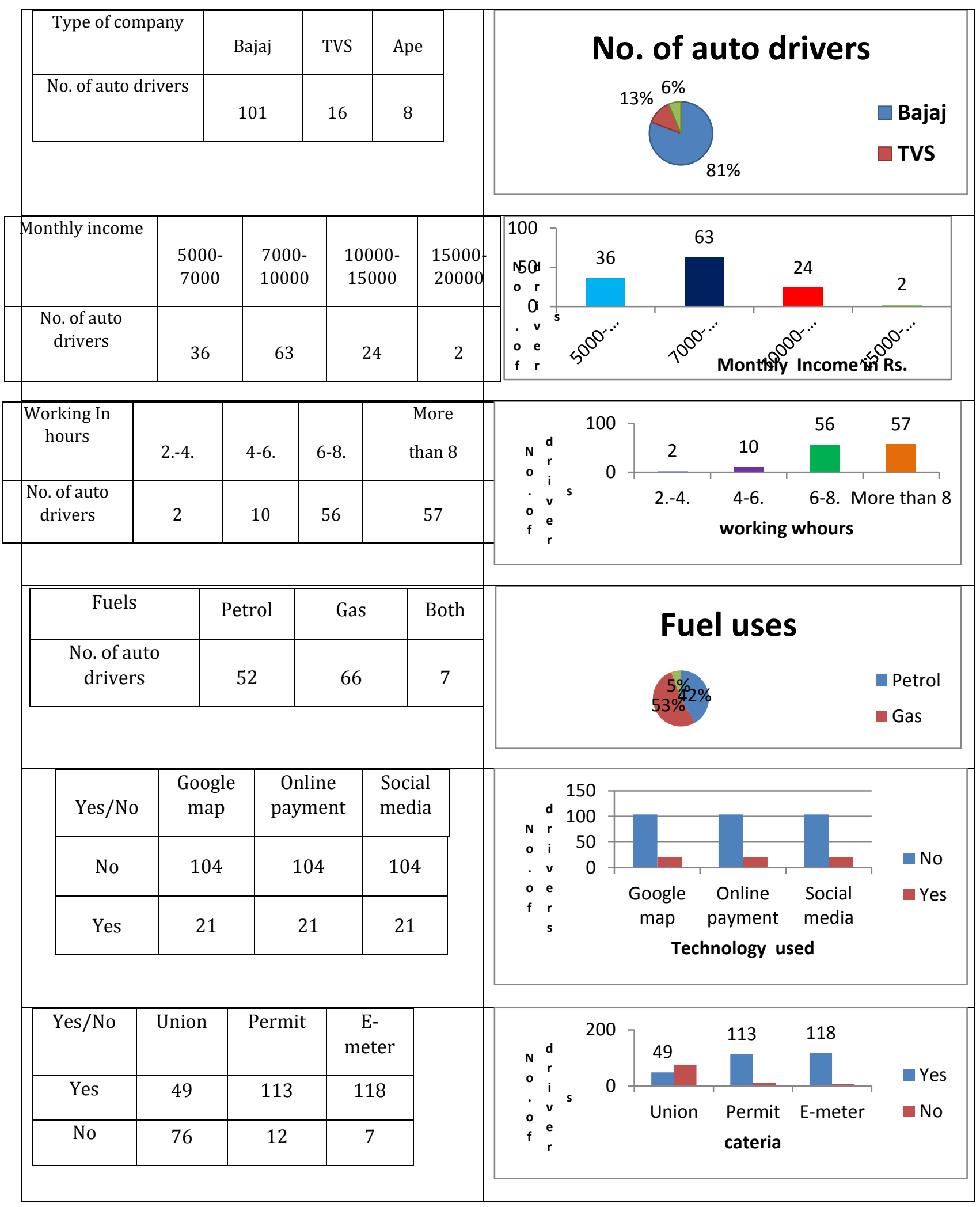


EPRA International Journal of Multidisciplinary Research (IJMR) - Peer Reviewed Journal

Volume: 6 | Issue: 11 |November 2020 || Journal DOI: 10.36713/epra2013 || SJIF Impact Factor: 7.032 ||ISI Value: 1.188

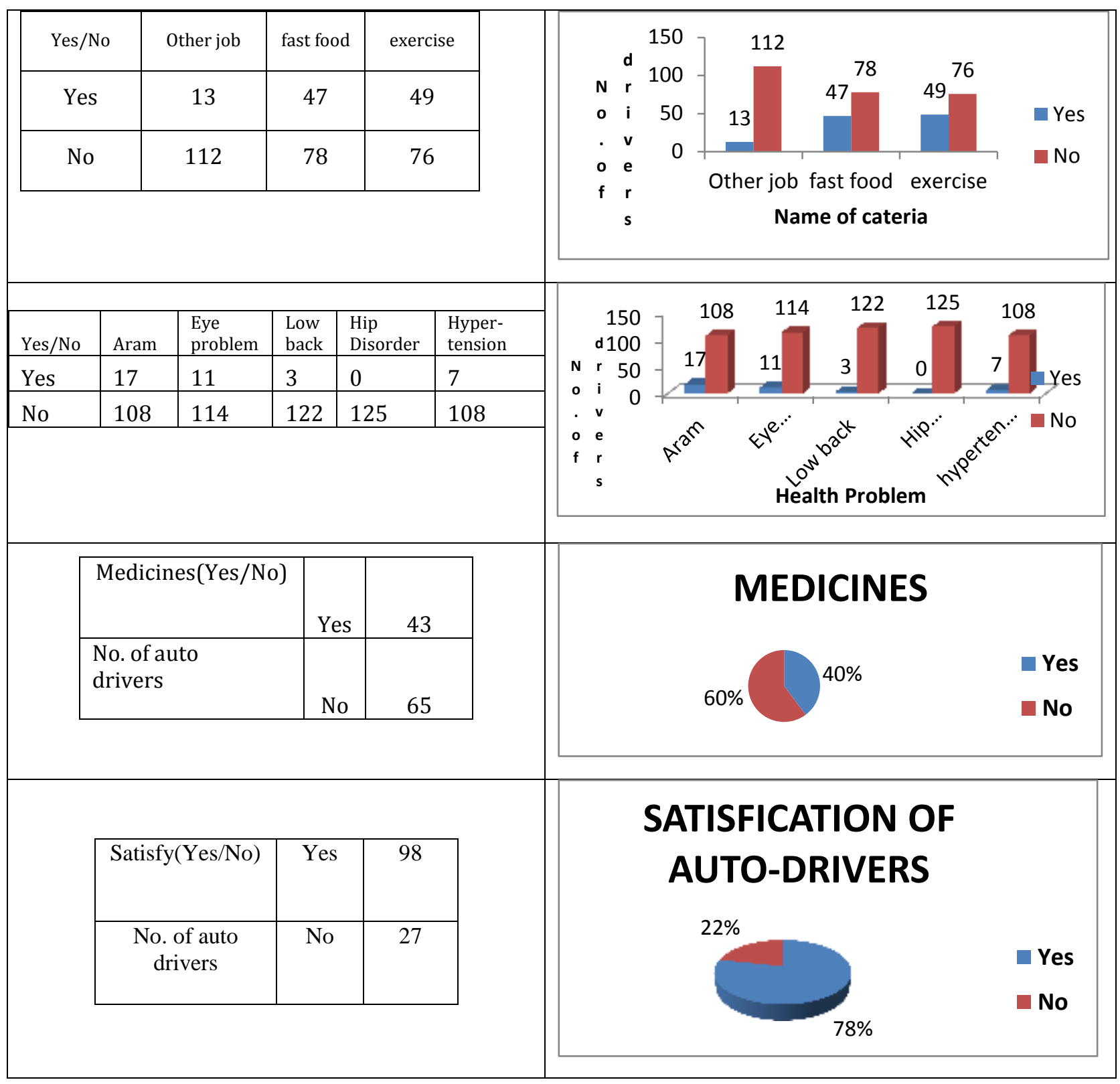

TESTING OF HYPOTHESIS

a) Test for independence between drive hours and health problem:

Hypothesis:

$\mathbf{H}_{\mathbf{0}}$ : Drive hour and health problem are independent.

$\mathbf{H}_{1}$ : Drive hour and health problem are not independent 
Observation Table:

\begin{tabular}{|c|c|c|c|c|c|}
\hline Hours/Health & No & Yes & $\begin{array}{c}\text { Grand } \\
\text { Total }\end{array}$ & & \\
\hline $2-4$ & 1 & 1 & 2 & & \\
\hline $4-6$ & 5 & 5 & 10 & & \\
\hline $6-8$ & 41 & 15 & 56 & & \\
\hline More than 8 & 49 & 8 & 57 & & \\
\hline Grand Total & 96 & 29 & 125 & & \\
\hline & & & \multicolumn{2}{|r|}{ Chi-square calculated } & 7.92 \\
\hline & & & \multicolumn{2}{|r|}{ Chi-square tabulated } & 7.81 \\
\hline & & & & DF & 1 \\
\hline & & & & \multirow{2}{*}{$\begin{array}{l}\text { p-value } \\
\text { Alpha }\end{array}$} & 0.037 \\
\hline & & & & & 0.05 \\
\hline
\end{tabular}

b) Test for independence between the area and monthly income

$\mathrm{H}_{0}$ : area and monthly income are independent.

$\mathrm{H}_{1}$ : area and monthly income are not independent.

\section{Observation Table:}

\begin{tabular}{|c|c|c|c|c|c|}
\hline Area/income & $\begin{array}{l}5000- \\
7000\end{array}$ & $\begin{array}{l}7000- \\
10000\end{array}$ & $\begin{array}{l}10000- \\
15000\end{array}$ & $\begin{array}{c}15000- \\
20000\end{array}$ & \\
\hline Rural & 15 & 13 & 5 & 0 & \\
\hline Urban & 21 & 50 & 19 & 2 & \\
\hline & & & \multicolumn{2}{|c|}{ Chi-square calculated } & 6.496 \\
\hline & & & \multicolumn{2}{|c|}{ Chi-square tabulated } & 7.815 \\
\hline & & & \multicolumn{2}{|l|}{$\mathrm{DF}$} & 3 \\
\hline & & & \multirow{2}{*}{\multicolumn{2}{|c|}{ p-value }} & 0.090 \\
\hline & & & & & 0.05 \\
\hline
\end{tabular}

c) Test for independence between the education and monthly income

$\mathrm{H}_{0}$ : The Education and monthly income are independent.

$\mathrm{H}_{1}$ : The Education and monthly income are not independent.

\section{Observation table}

\begin{tabular}{|c|c|c|c|c|c|c|}
\hline Education/Income & $\begin{array}{l}5000- \\
7000 \\
\end{array}$ & $\begin{array}{l}7000- \\
10000 \\
\end{array}$ & $\begin{array}{l}10000- \\
15000\end{array}$ & $\begin{array}{l}15000- \\
20000 \\
\end{array}$ & $\begin{array}{l}\text { Chi-square } \\
\text { calculated }\end{array}$ & 19.723 \\
\hline HSC & 5 & 14 & 2 & 1 & \multirow{2}{*}{$\begin{array}{l}\text { Chi-square } \\
\text { tabulated }\end{array}$} & \multirow[b]{2}{*}{28.869} \\
\hline Illiterate & 0 & 2 & 0 & 0 & & \\
\hline PG & 0 & 0 & 1 & 0 & DF & 18 \\
\hline & & & & & $p$-value & 0.349 \\
\hline SSC & 10 & 27 & 10 & 1 & alpha & 0.05 \\
\hline UG & 3 & 3 & 4 & 0 & & \\
\hline below 5th & 3 & 2 & 2 & 0 & & \\
\hline below SSC & 15 & 15 & 5 & 0 & & \\
\hline
\end{tabular}


d) Test for independence between education and family insurance

$\mathrm{H}_{0}$ : Education and family insurance are independent.

$\mathrm{H}_{1}$ : Education and family insurance are not independent.

Observation table:

\begin{tabular}{|l|l|l|}
\hline Education/insurance & Yes & No \\
\hline HSC & 12 & 10 \\
\hline Illiterate & 2 & 0 \\
\hline PG & 0 & 1 \\
\hline SSC & 21 & 27 \\
\hline UG & 4 & 6 \\
\hline below 5th & 7 & 0 \\
\hline below SSC & 14 & 21 \\
\cline { 2 - 5 }
\end{tabular}

e) Test for independence between education and loan:

$\mathrm{H}_{0}$ : Education and loan are independent.

$\mathrm{H}_{1}$ : Education and loan are not independent.

Observation Table

\begin{tabular}{|c|c|c|c|}
\hline Education/loan & Yes & NO & Total \\
\hline HSC & 10 & 12 & 22 \\
\hline Illiterate & 0 & 2 & 2 \\
\hline PG & 0 & 1 & 1 \\
\hline SSC & 22 & 26 & 48 \\
\hline UG & 7 & 3 & 10 \\
\hline below 5 th & 3 & 4 & 7 \\
\hline below SSC & 18 & 17 & 35 \\
\hline
\end{tabular}

\begin{tabular}{|l|l|}
\hline Chi-square calculated & 5.095 \\
\hline Chi-square tabulated & 12.592 \\
\hline DF & 6 \\
\hline p-value & 0.532 \\
\hline alpha & 0.05 \\
\hline
\end{tabular}

f) $\mathrm{Z}$ test of rural and urban auto drivers

Ho: $\mu 1=\mu 2$ and $\mathrm{H} 1: \mu 1 \neq \mu 2$

\begin{tabular}{|l|c|c|}
\hline & Owner & Rental \\
\hline Mean & 419.7692 & 319.625 \\
\hline Known Variance & 7347.391 & 2160.984 \\
\hline Observations & 117 & 8 \\
\hline Hypothesized Mean Difference & 0 & \\
\hline Z & 5.488519 & \\
\hline z Critical one-tail & 1.644854 & \\
\hline P(Z<=z) two-tail & $4.05 E-08$ & \\
\hline z Critical two-tail & 1.959964 & \\
\hline
\end{tabular}

g) F-test for equality of two variance

$\mathrm{H}_{0}: \sigma 1=\sigma 2$ and $\mathrm{H}_{1}: \sigma 1 \neq \sigma 2$

\begin{tabular}{|c|c|c|}
\hline \multicolumn{3}{|c|}{} \\
\hline & Rural & Urban \\
\hline Mean & 379.9697 & 425.337 \\
\hline Variance & 7935.03 & 7122.182 \\
\hline Observations & 33 & 92 \\
\hline $\mathrm{df}$ & 32 & 91 \\
\hline $\mathrm{F}$ & 1.114129 & \\
\hline $\mathrm{P}(\mathrm{F}<=\mathrm{f})$ one-tail & 0.337287 & \\
\hline $\mathrm{F} \mathrm{Critical} \mathrm{one-tail}$ & 1.570625 & \\
\hline
\end{tabular}




\section{h) Test for proportion of auto driver stay in simple house}

Let,

$\mathrm{n}$ : Sample of auto driver

$\mathrm{x}$ : No. of auto driver has simple house

p: Sample proportion of auto driver has simple house

$$
=\frac{x}{n}=0.60
$$

Level of significance, $\alpha=5 \%$

\section{Hypothesis}

$$
\mathrm{H}_{0}: \mathrm{P}=0.65 . \quad \mathrm{V} / \mathrm{s} \quad \mathrm{H}_{1}: \mathrm{P} \neq 0.65
$$

$$
\left|Z_{0}\right|=1.1702
$$

Critical value $=\mathrm{Z}_{\mathrm{a} / 2}=1.96$

\section{i)Test for proportion of auto drivers are taking loan in central bank}

Let, n: Sample of auto Driver

$\mathrm{x}$ : No. of auto drivers have loan at central bank

$\mathrm{p}$ : sample proportion of taking loan in central bank

Level of Significance, $\alpha=5 \%$

\section{Hypothesis}
$\mathrm{H}_{0}: \mathrm{P}=0.4$
$\mathrm{V} / \mathrm{s}$
$\mathrm{H}_{1}: \mathrm{P} \neq 0.4$

\section{Calculation}

$\left|\mathrm{Z}_{0}\right|=1.6431$

Critical value $=Z_{\alpha / 2}=1.96$

j) Test for proportion of auto driver use bajaj auto company

Let,

$\mathrm{n}$ : Sample of auto driver

x: No. of auto drivers use bajaj auto company

$\mathrm{p}$ : Sample proportion of use bajaj auto company

Level of significance, $\alpha=5 \%$

\section{Hypothesis}
$\mathrm{H}_{0}: \mathrm{P}=0.85$
$\mathrm{V} / \mathrm{s}$
$\mathrm{H}_{1}: \mathrm{P} \neq 0.85$

Calculation: $\quad\left|\mathrm{Z}_{0}\right|=0.2236$

Critical value $=Z_{\alpha / 2}=1.96$

\section{k) Test for proportion of auto driver use gas as fuel}

Let,

$\mathrm{n}$ : Sample of auto driver

$\mathrm{x}$ : No. of auto drivers use gas as fuel

$\mathrm{p}$ : Sample proportion of use gas as fuel

Level of significance, $\alpha=5 \%$

\section{Hypothesis}
$\mathrm{H}_{0}: \mathrm{P}=0.60$.
$\mathrm{V} / \mathrm{s}$
$\mathrm{H}_{1}: \mathrm{P} \neq 0.60$

$\left|\mathrm{Z}_{0}\right|=1.6431$ 
Critical value $=Z_{\alpha / 2}=1.96$

\section{ANOVA TEST (CRD) \\ The Testing of equality average of Different types of Companies of auto Drivers Hypothesis:}

$\mathrm{H}_{0}: \mu 1=\mu 2=\mu 3=\mu 4$ i.e. There is no significant difference between Companies of Auto Drivers

Where $\mu 1$ : Bajaj, $\mu 2$ : TVS, $\mu 3$ : Ape, $\mu 4$ : Other

\section{ANOVA}

\begin{tabular}{|l|l|l|l|l|l|l|}
\hline Source of Variation & SS & df & MS & F & P-value & F crit. \\
\hline Between Groups & 3241.372 & 2 & 1620.686 & 0.208396 & 0.812174 & 3.070512 \\
\hline Within Groups & 948787.4 & 122 & 7776.946 & & & \\
\hline Total & 952028.8 & 124 & & & & \\
\hline
\end{tabular}

\section{MAJOR FINDING}

Our study shows that the maximum auto drivers are lives in urban area in simple house,most of auto drivers are married and maximum of are taking bank loan for buying auto rickshaw. They are prepared Central Bank for taking Bank loan.Number auto drivers are taking family insurance as well as insurance for auto rickshaw. Bajaj Auto companys rickshaw preferred by most of drivers the montly income is Rs. 7000-10000.and auto drivers have minimum one vehicle.they driving in daily more than eight hours.and uses gas and petrol for fuel options.auto drivers are waiting for Passenger are nearly about one-two hours.most of the auto drivers are not use Smartphone and doesn't aware about the technology. The most of the auto drivers are does not include in Union, almost every auto has permit, and most of the auto drivers use e-meters and are do not work in others job. Almost auto-drivers though lot of people do not have any exercise regime they also do not any fast food.most of the auto drivers are faced aram and eye related issues, and none of the auto rickshaw drivers have problem related to hip disorder.They does not use in medicine.mostly auto drivers are satisfy in their work and income. Finally conclude that drive hours and health problem are not in dependent but area and monthly income are dependent. Auto drivers education and their monthly income are independent. And there is significant difference between education monthly incomes. education and family insurance are not independent There is no significance difference between education and loan.

\section{REFERENCES}

1. Rajesh Rajan,(2015). "A study on work life balance of Auto rickshaw drivers in Mumbai." IOSR Journal of Humanities and Social Sciences, volume 20, Issue 1, pp106-111.

2. M.Yesurajan and D.T.Indira,(2017) . "Common work related health problems of auto rickshaw drivers in India-causes and strategies", International Journal of Applied Research, p232- 236.

3. Gupta, S.P., (2013). Statistical Methods, Educational Publishers. New Delhi.

4. Kartikeyan, S., Gurav, R.B., Joshi, S.D., \& Wayal, R. (2004). Health and socio-demographic profile of transport workers, Indian journal of occupational and environmental medicine. 8(2), 8

5. Kumar, M., Singh, S., Ghate, A. T., Pal, S., \& Wilson, S. A. (2016). Informal Public Transport Modes in India: A Case Study of Five City Regions. IATSS Research, 39(2).

6. Maciulyte, N. (2000, October). Bus drivers' health and conditions of work, In Symposium conducted at the European Centre for Occupational Health. Safety and the Environment, Kaunas, Lithuania.

7. Sabbagh-Ehrlich, S., Friedman, L., \& Richter, E.D. (2005). Working conditions and fatigue in professional truck drivers at Israeli ports. Injury Prevention. 11(2), 110-114.

8. Singh, S.P., Misra, S.K., Chaudhary, S.S., Katyal, R., Singh, A., \& Joshi H.S., (2015). Heath status of auto rickshaw drivers plying in Agra city, MedPulse - International Medical Journal. 2(4), 221-228, http://www.medpulse.in.

9. Winkleby, M.A., Ragland, D.R., Fisher, J.M., \& Syme, S.L., (1998). Excess risk of sickness and disease in bus drivers: a review and synthesis of epidemiological studies. International Journal of Epidemiology. 17(2), 255-262.

10. Rajesh Rajan,(2015). "A study on work life balance of Auto rickshaw drivers in Mumbai." IOSR Journal of Humanities and Social Sciences, volume 20, Issue 1, pp106-111.

11. M.Yesurajan and D.T.Indira,(2017) . "Common work related health problems of auto rickshaw drivers in India-causes and strategies", International Journal of Applied Research, p-232- 236. 